\title{
SABERES E SABORES: TRADIÇÕES CULTURAIS POPULARES DO INTERIOR DE MINAS E DE GOIÁS
}

\section{Lore and Luscious: Traditions from Minas Gerais and Goiás (Brazil) Countryside Popular Cultures}

\author{
Mônica Chaves Abdala*
}

\begin{abstract}
RESUMO
Pretendemos neste artigo tratar em conjunto duas experiências distintas de pesquisas realizadas nas regiões do Triângulo e Alto Paranaíba, em Minas Gerais, e no sudeste de Goiás. Advindas de proposições diferenciadas, apresentaram procedimentos analíticos também diferenciados, tendo em comum o registro de memórias, coletadas por meio da história oral, com vistas à "preservação do patrimônio histórico cultural". Dispusemo-nos ao desafio de refletir sobre "patrimônio, memória e saberes e práticas alimentares" tendo em vista as relações existentes entre história, cultura e alimentação. A questão norteadora foi: admitindo-se as inevitáveis transformações pelas quais passam as manifestações culturais tradicionais, como pensar o sentido de continuidade das tradições no âmbito local? Percebemos que saberes e práticas cotidianas são reapropriados e ressignificados por aqueles que lhes dão vida, nas diferentes manifestações e nas diferentes posições que ocupam como produtores, consumidores, órgãos públicos, organizadores, participantes e apoiadores como agentes culturais ou pesquisadores.
\end{abstract}

Palavras-chave: práticas culturais populares; tradições alimentares; memória.

\footnotetext{
ABSTRACT

We intend in this article to present two distinct experiences of research carried through in the regions of the Triângulo Mineiro and Alto Paranaíba, Minas Gerais, and the southeast of Goiás (Brazil). The studies

* Doutora em Sociologia. Docente do Departamento de Ciências Sociais/Faculdade de Artes, Filosofia e Ciências Sociais, do Programa de Pós-Graduação em História e do Mestrado em Ciências Sociais/Universidade Federal de Uberlândia. E-mail: mcabdala@ufu.br
} 
happened with proposals and analytical procedures differentiated, having in common the register of memories, collected by verbal history, objectifying the "preservation of cultural historic patrimony". We accepted the challenge to reflect about the "patrimony, memory and knowledge and alimentary practices", considering the relations that exist between history, culture and food. The question that guided us through was: admitting the inevitable transformations that circumscribe the traditional cultural manifestations, how can we think about the sense of continuity in the local scope traditions? We perceive that, the knowledge and daily practices are reworked and gain new meaning in the different manifestations and the different positions that the individuals occupy as producers, consumers, public agencies, participants and supporters as cultural agents or searching.

Key-words: popular cultural practices; alimentary traditions; memory.

\section{Introdução}

Trago, nas mãos, uns fios de água que apanhei das memórias do rio... Ponho-me a tecer lembranças...

(OLIVEIRA; BRANDÃO) $^{1}$

Apanhar memórias, tecer lembranças: uma feliz expressão para pesquisas que se propõem documentar saberes e práticas cotidianas do interior do país, enfocando as tradições, suas permanências e mudanças.

Pretende-se aqui refletir em conjunto sobre duas experiências distintas de pesquisas fundadas na compreensão do espaço local como categoria central de observação. A preocupação de ambas com o registro de memórias, coletadas por meio da história oral, inspirou semelhante tratamento. $\mathrm{O}$ fato de comporem micro-histórias plenas de representações e significados possibilitou a reconstituição de quadros histórico-culturais.

1 OLIVEIRA, J. A.; BRANDÃO, C. R. Entre o murmúrio do rio e o despertar das lembranças. In: RAMIRES, J. C. L.; PESSÔA, V. L. S. (Org.). Geografia e pesquisa qualitativa: nas trilhas da investigação. Uberlândia: Assis Editora, 2009. p. 221. 
Trata-se de uma reflexão visando reconstituir processos históricos por meio de expressões particularizadas ${ }^{2}$ da forma como foram vivenciados no cotidiano de homens e mulheres que cultivam tradições ancestrais. $\mathrm{O}$ pressuposto básico é que coletar memórias significa recompor processos coletivos a partir do relato individual de fatos da cultura tradicional popular nem sempre registrados. Tais fatos se relacionam a modos de vida fundados na experiência coletiva, permeada por formas de cooperação, solidariedade e vizinhança, em meios rurais e pequenas cidades que se tornaram "centros rurais urbanizados"3. Também podem ser apreendidos por meio da valorização e ressignificação das tradições em meio à vida urbana.

Ambas as experiências de pesquisa se tornaram possíveis graças a oportunidades de registro da cultura imaterial com vistas à "preservação de patrimônio histórico cultural". Advinham de proposições diferenciadas, o que determinou procedimentos analíticos também diferenciados. No entanto, repensando trajetórias de pesquisa e buscando, à luz do tema proposto, contribuir para o debate, nos dispusemos ao desafio de refletir sobre "patrimônio, memória e saberes e práticas da alimentação", tendo em vista as relações existentes entre história, cultura e alimentação.

Algumas questões nortearam a reflexão aqui desenvolvida, como já apontáramos no livro Caleidoscópio..., cuja metáfora, nos dizeres de Machado, significa que: "[...] cada novo olhar estimula nossa imaginação. Fluida e móvel, a cultura popular, como um camaleão, induz sempre a novas imagens, a outras práticas ou (re) significa velhos ofícios, num saber fazer em construção"4.

2 Sobre a relação entre memória individual e coletiva lembramos a clássica obra de Ecléa Bosi, para quem: “[...] o modo de lembrar é tão individual quanto social: o grupo transmite, retém e reforça as lembranças, mas o recordador, ao trabalhá-las, vai paulatinamente individualizando a memória comunitária e, no que lembra e no como lembra, faz com que fique o que signifique. O tempo da memória é social, não só porque é o calendário do trabalho e da festa, do evento político e do fato insólito, mas também porque repercute no modo de lembrar". BOSI, E. Memória e sociedade: lembranças de velhos. São Paulo: Companhia das Letras, 1994. p. 31.

3 Oliveira analisa as pequenas cidades do entorno de Catalão que pesquisamos, afirmando que se tornaram centros rurais urbanizados. "Em termos econômicos nota-se [...] que o percentual da população ocupada com a atividade rural é maior que o percentual da população que vive no meio rural, o que comprova a tese do 'part-time agriculture', ou agricultura em tempo parcial. É comum o deslocamento diário de pessoas, tanto proprietários como empregados, às propriedades, mas que mantêm moradia e outras atividades nas cidades". OLIVEIRA, César Antônio. A sobrevivência da ruralidade no entorno de Catalão-GO frente à modernização da agricultura do Centro-Oeste brasileiro. Revista do Centro de Ensino Superior de Catalão, CESUC, ano 4, n. 6, p. 8, 1. sem. 2002.

4 MACHADO, M.C. T. Tesouros do interior das Gerais. In: MACHADO, M. C. T.; ABDALA, M. C. (Org.). Caleidoscópio de saberes e práticas populares. Catálogo de produção cultural do Triângulo Mineiro e Alto Paranaíba. Uberlândia: EDUFU, 2007. 
Desta forma, o registro e o estudo da cultura imaterial nos colocaram de pronto, diante da dificuldade de delimitar as práticas e saberes populares a serem analisados. Pareceu fundamental, em primeiro lugar, reconhecer sua dinâmica sem restringi-la a "resquícios vivos de um passado", a ser inventariado e preservado romanticamente. Foi necessário também reconhecer as diferenças entre as pessoas que são portadoras de saberes e dão vida a tais práticas, tais como produtores, vendedores, consumidores, funcionários de órgãos públicos que apoiam pequenos produtores, aqueles que as organizam, os que delas participam e os que as apoiam como agentes culturais ou pesquisadores (ABDALA, 2007b).

Inspiradas no debate que se estabeleceu desde o Seminário de Políticas Públicas para as Culturas Populares, realizado em Brasília em 2005, tratava-se também, como sugeriu Cavalcanti, de favorecer o registro da memória e apreender "o sentido de continuidade no âmbito da cultura", sem cair na armadilha de pretender tipificar uma cultura "supostamente autêntica"s.

Desse modo, por meio do estudo de hábitos alimentares e formas de sociabilidade buscamos analisar o fazer de cada coletividade e o modo como a afirmação do local se faz presente entendendo, como Canclini ${ }^{6}$, os hábitos tradicionais como representações do modo de vida daqueles que os produzem e reafirmam.

\section{Propostas para diagnósticos de cultura imaterial: duas experiências de pesquisa}

A primeira pesquisa, no final de 2006 e início de 2007, em cidades do Triângulo Mineiro e Alto Paranaíba, resultou de um projeto aprovado pela

5 CAVALCANTI, Maria Laura V. C. Culturas populares: múltiplas leituras. In: SEMINÁRIO NACIONAL DE POLÍTICAS PÚBLICAS PARAAS CULTURAS POPULARES, 2., 2005, Brasília. Anais... São Paulo: Instituto Pólis; Brasília, DF: Ministério da Cultura, 2005. p. 28-37.

6 CANCLINI apud CARVALHO, José Jorge. O lugar da cultura tradicional na sociedade moderna. Brasília, DF: UnB, 1989. p. 7. (Série Antropologia, n. 77). 
Lei Estadual de Incentivo à Cultura ${ }^{7}$, o que pressupôs captação de recursos e, desta forma, o condicionamento do tempo e do material da pesquisa ao montante de recursos captados. Diante desse fato, um número restrito de cidades foi analisado: Araxá, Frutal, Ituiutaba, Patos de Minas, Patrocínio, Uberaba e Uberlândia ${ }^{8}$. As incursões ao campo foram feitas num período de três meses, em que se procurou registrar em gravações e imagens o maior número possível de práticas e saberes da cultura popular na região demarcada, enfatizando artesanato, culinária, festas e religiosidade. Se, por um lado, a forma de financiamento estabeleceu limites de tempo e, consequentemente, recortes quanto ao que seria analisado, o processo permitiu relativa autonomia, sem censura e vigilância constantes dos procedimentos analíticos e metodológicos da equipe interdisciplinar de pesquisadores.

$\mathrm{O}$ ponto de referência eram práticas e saberes nas cidades, o que poderia nos conduzir a certa ênfase nas experiências vivenciadas no presente, na ocasião mesma da observação: o fazer em ação. No entanto, não descuidamos do relato de memórias, procurando apreender a história das práticas e saberes analisados, na perspectiva de recuperar seus processos de constituição e as mudanças em curso. Também, sempre que possível, perscrutamos as relações entre as expressões culturais analisadas no meio urbano e possíveis fundamentos e heranças rurais.

Entretanto, o grupo de pessoas que constituiria nosso grupo de entrevistados determinou um corpus com características bem definidas: eram aqueles homens e mulheres que participavam ativamente dos processos objetos de nosso estudo - os artesãos e artesãs dos teares manuais, da palha de milho, da madeira, das fibras vegetais, do tecido (as bonequeiras); os escultores; os cuteleiros; os lutiers; os construtores de carro de boi; as doceiras e cozinheiras; os fabricantes de cachaça, de farinhas, de polvilho, de queijos; os foliões e componentes de ternos de congada; os devotos que trabalhavam nos bastidores das comemorações religiosas; benzedores e benzedoras.

Esses verdadeiros "tesouros" de saberes com os quais nos deparamos não pareciam desamparados e ameaçados frente aos processos de

7 A captação de recursos para a pesquisa, uma vez aprovada pela Lei estadual, foi realizada junto ao Instituto Algar - Grupo ABC, de Uberlândia, que financiou parte do trabalho com apoio da Universidade Federal de Uberlândia.

8 O critério de seleção adotado foi o fato de serem cidades sedes representativas das duas microrregiões estudadas. 
modernização, tecnificação e "mundialização" da cultura". Muitos deles estavam organizados em associações e cooperativas, outros envolvidos com cursos profissionalizantes e de aperfeiçoamento promovidos por agências governamentais ou mesmo patrocinados pelos poderes municipais, por meio de políticas para a cultura. Poucos permaneciam à margem desse diálogo com agentes diferenciados envolvidos no processo de "preservação do patrimônio histórico-cultural" e de sua divulgação, a exemplo dos meios de comunicação, constantemente documentando os eventos.

A outra experiência, durante o ano de 2009, resultou da participação no Programa de Preservação do Patrimônio Histórico-Cultural da SEFAC Energia S/A. ${ }^{10}$ e se pautou nas diretrizes de seu Programa Básico Ambiental (PBA) e no Termo de Referência (TR) cuja determinação era: “[ [...] constituir um instrumento de pesquisa dos fenômenos culturais, a fim de identificar as manifestações que representam traços marcantes do universo sob a influência do empreendimento" "11. A área de abrangência correspondeu aos municípios de Campo Alegre de Goiás, Catalão, Cristalina, Davinópolis e Ipameri no sudeste goiano e de Paracatu, em Minas Gerais. Recursos orçamentários foram programados em função da metodologia e das necessidades previamente discutidas e aprovadas e a pesquisa foi desenvolvida ao longo de um ano, com uma equipe que envolveu pesquisadores e estagiários das áreas de história, sociologia, geografia e biologia, fazendo registros em imagens e gravações e contando com uma pessoa especializada em filmagens com vistas à produção de um vídeo.

Recursos disponíveis, equipe numerosa e maior tempo possibilitaram um registro bem mais detalhado do que na pesquisa anterior; no entanto, ocorreram dificuldades provenientes das tensões advindas de vigilância constante, intervenções nos procedimentos de análise e de crítica da documentação coletada e, não raras vezes, tentativas de privilegiar falas positivas sobre o empreendimento, o que se contrapunha à nossa proposta explícita no projeto inicial de dar voz a todas as pessoas afetadas direta e indiretamente pela construção da Usina. Perspectiva que nos conduziria a

9 Cf. ORTIZ, Renato. Mundialização e cultura. São Paulo: Brasiliense, 1994.

10 A pesquisa foi aprovada pela Agência Intelecto/Pró-Reitoria de Pesquisas e Pós-Graduação da Universidade Federal de Uberlândia e financiada pelo consórcio SEFAC Energia S/A.

11 Cf. UHE SERRA DO FACÃO. Projeto Básico Ambiental. Programa de Preservação do Patrimônio Histórico-Cultural, abril, 2002, p. 4. 
procedimento metodológico diverso daquele adotado na pesquisa anterior.

Tratava-se de um grupo em eminente situação de perda, cujas memórias certamente seriam afetadas por tal situação. Além do mais, por meio das narrativas de um conjunto bastante heterogêneo de pessoas teríamos de recuperar experiências diversificadas de vida e, neste novo contexto, as expressões culturais reveladas na religiosidade, nas artesanias e artes do fazer, privilegiadas na primeira pesquisa, se configuravam como partes de um amplo conjunto de relações sociais e saberes que deveriam ser registrados avaliando-se as possibilidades mesmas de sua permanência.

Era fundamental perceber em que medida não apenas as inovações tecnológicas, a modernização do campo e os processos de "mundialização da cultura" provocavam mudanças nos modos de vida das comunidades estudadas, mas também a contribuição da perda de seu lugar ancestral e dos laços de sociabilidade e vizinhança para esse processo. Além disso, era preciso considerar que a forma como expressavam e sentiam essa perda afetaria suas memórias e seus relatos.

Diante do quadro apresentado, a documentação propiciada foi, sem dúvida, bem mais ampla. Foi possível documentar diferentes modos de viver e se organizar no cotidiano, assim como as formas de sociabilidade, a religiosidade, as trocas culturais com migrantes, o diálogo entre práticas tradicionais e modernização, as trajetórias das mulheres do campo, encarregadas do espaço doméstico - que inclui o cuidado dos filhos e da casa, dos animais e quintais que lhe são próximos -, mas também participando em toda labuta diária: o reparo da cerca, a colheita, o cuidado do pasto e da roça, laçar o gado, tirar o leite... Destacaram-se ainda aspectos do patrimônio material e imaterial: cozinha tradicional, jogo de truco, benzeções, cura por meio de plantas, festividades religiosas (folias ${ }^{12}$, congadas, terços cantados, festas "de roça"13 e juninas), artesanatos e artes do fazer (fabri-

12 Folias são formas de festejos difundidas no Brasil desde a época da colonização, ligadas às comemorações do culto católico do Natal. A prática foi recriada, principalmente no interior, e estendida às celebrações em homenagens a outros santos que não os "santos-reis". É comum em Minas e em Goiás a realização das Folias de Reis no período natalino. Em Goiás há também outras festividades com a presença das folias em épocas distintas, como é o caso das comemorações ao Divino Espírito Santo e São Sebastião. A esse respeito consultar: quadro síntese das festas elaborado por KATRIB, C. M. In: KATRIB, C. M.; MACHADO, M. C. T.; ABDALA, M. C. (Org.). São Marcos do sertão Goiano. Uberlândia: EDUFU, 2010.

13 Festa de roça é uma categoria nativa e se refere às festas de comunidades para comemorar santos padroeiros. Começam no mês de março e vão até agosto. Duram de 7 a 9 dias e tradicionalmente têm terços, missas, leilões e bailes. No último dia, serve-se um almoço comunitário com mesa de doces. 
cação de farinhas, queijos, doces, requeijões, sabão, dentre outras). Também foram citados costumes que hoje permanecem apenas nas memórias, como mutirões, cantigas, brinquedos feitos de milho e de outras plantas e a experiência de parteiras.

A presença de cursos de formação propiciados pelo poder público se fez notar nos relatos sobre aprendizado de procedimentos culinários e artesanato como bordados, pinturas em tecido, dentre outros. O diálogo com agentes envolvidos no processo de "preservação do patrimônio histórico-cultural" e de sua divulgação se expressou nas manifestações culturais organizadas, como a Folia do Divino, em Campo Alegre, e as Folias de Reis e Congada, em Catalão, que, em virtude de suas características (ocupam espaços públicos, envolvem grande número de pessoas), mantêm comunicação direta com os representantes do poder local e atraem meios de comunicação. Algumas prefeituras apoiam eventos de preservação da cultura local, a exemplo do encontro das fiandeiras e dos violeiros em Campo Alegre de Goiás, quando acontecem exposições de artesanato, cachaça e produtos da culinária.

Em ambos os projetos, a proposta não foi realizar um inventário a partir da metodologia proposta pelo IPHAN (Instituto do Patrimônio Histórico e Artístico Nacional) ${ }^{14}$. Ainda assim, os livros escritos sobre as pesquisas ${ }^{15}$, o conjunto de imagens e a vasta documentação produzida ${ }^{16}$ propiciaram um inequívoco diagnóstico da cultura popular nas regiões estudadas $^{17}$.

14 Sobre inventários de patrimônio imaterial consultar: LONDRES, Cecília. Os inventários nas políticas de patrimônio imaterial. In: Celebrações e saberes da cultura popular: pesquisa, inventário, crítica, perspectivas. Rio de Janeiro: Funarte, IPHAN, CNFCP, 2004. p. 7-14; VIANNA, Letícia. Patrimônio imaterial: legislação e inventários culturais. In: Celebrações e saberes da cultura popular: pesquisa, inventário, crítica, perspectivas. Rio de Janeiro: Funarte, IPHAN, CNFCP, 2004.

15 ABDALA, M. C.; MACHADO, M.C. T. (Org.). Caleidoscópio de saberes e práticas populares. Catálogo de produção cultural do Triângulo Mineiro e Alto Paranaíba. Uberlândia: EDUFU, 2007. Também KATRIB, C. M.; MACHADO, M. C. T.; ABDALA, M. C. (Org.). Op. cit., 2010.

16 Em relação ao projeto da SEFAC, a Universidade Federal de Goiás abrigará um Centro de Referência destinado aos acervos do Patrimônio Histórico e Cultural, do Patrimônio Arqueológico e do Programa de Educação Ambiental, no Campus de Catalão/GO.

17 A respeito de nossa opção pelo recurso metodológico de um "[...] diagnóstico sobre a realidade cultural em um processo ininterrupto de mudanças", ao invés de um inventário, ver: MACHADO, M. C. T. Tesouros do interior das Gerais: cenários, percursos e reencontros com a cultura popular. In: ABDALA, M. C.; MACHADO, M.C. T. (Org.). Op. cit., 2007. 
Neste artigo, abordamos o tema dos saberes e práticas da alimentação observados nos três municípios do sudeste goiano que têm a maior área afetada pelo empreendimento hidrelétrico: Campo Alegre, Catalão e Davinópolis. O recorte é um recurso analítico que se impõe sem, no entanto, perder de vista o fato de que são indissociáveis, na prática, de aspectos como religiosidade, festas com muita diversão, fartura e sociabilidade. Também as artes do fazer, assim como os modos de viver as relações sociais ou os papéis sexuais estão imbricados em tais saberes e práticas. Nenhum desses aspectos está dissociado.

A opção pelo estudo das tradições alimentares regionais se deve à convicção de que a cozinha é elemento central para a compreensão de manifestações da cultura imaterial, propiciando apreensão de valores, de modos de vida, de significados simbólicos, como também da construção de identidades, seja em âmbito local, regional ou nacional, como temos apontado em nossos trabalhos ${ }^{18}$. Vários estudiosos também têm se dedicado a esse enfoque, não apenas no Brasil. A título de exemplo, citamos a Dra. Cristina Padilla Dieste, da Universidad de Guadalajara, que sintetiza muito bem essa questão:

Las cocinas regionales constituyen una de las expresiones culturales más contundentes de lo que se ha denominado el patrimonio intangible de las sociedades y las comunidades. Dicho patrimonio intangible u oral se distingue por su capacidad de evocar valores, sabores, modos, estilos, sazones que en cada ocasión se materializan en un platillo o una manufactura para el paladar y la celebración. Por ello en torno a las cocinas, históricamente se han organizado las sociedades dando forma a una gama inmensa de estilos de vida relacionadas con la producción en el campo, los sistemas de abasto y comercialización de alimentos, las técnicas y procedimientos de prepararlos, los artefactos y objetos de uso y los modos de compartir la mesa. Es decir que los alimentos forman parte fundamental de las economías regionales y locales y su conservación, preservación

18 Além dos livros: ABDALA, M. C. Receita de mineiridade. 2. ed. Uberlândia: EDUFU, 2007; MACHADO; ABDALA, 2007; KATRIB; MACHADO; ABDALA, 2010, também em vários de nossos artigos temos nos dedicado a refletir sobre a relação entre cozinha, cultura e identidade. 
y aprecio posibilitan estimular su potencial e impacto sobre otras vertientes de la vida material y simbólica de cada lugar ${ }^{19}$.

Uma ampla gama de aspectos foi analisada, como produtos e ingredientes mais utilizados nas regiões estudadas; locais de produção e de consumo de alimentos; modos de preparação e conservação (com registro de receitas); locais de aquisição ou, em alguns casos, de venda (feiras, mercados, lojas especializadas, vendas caseiras); consumo em festas religiosas e ocasiões de encontros; determinantes históricas (análise do abastecimento e da origem de hábitos alimentares). Também foi dada atenção aos fatores de ordem socioeconômica que provocaram alterações nos hábitos culturais, nos alimentares em particular.

Devido às características do grupo de entrevistados em Minas, ressaltamos o que se come nas festanças - como a Folia de Reis e a Congada - e as comidas, os doces, as quitandas ${ }^{20} \mathrm{e}$ cachaças feitos por pequenos produtores e donas de casa, que transformaram o saber doméstico em meio de ganhar a vida, comercializando seus produtos de formas variadas, inclusive em feiras livres ou promovidas pela EMATER (Empresa de Assistência Técnica e Extensão Rural). Destacaram-se, neste aspecto, pequenos estabelecimentos de comida caseira tida como "típica mineira" em que os cozinheiros eram os próprios proprietários. Os hábitos alimentares do dia a dia nas casas e as memórias de costumes que não são mais vivenciados nos dias atuais não foram referidos pelo grupo pesquisado ${ }^{21}$.

As informações sobre práticas alimentares tradicionais do sudeste goiano, por sua vez, incluem memórias de tradições que hoje praticamente não são realizadas, além de diversas comemorações - folias, congadas, festas "de roça", juninas, dentre outras -; da produção de cachaça e da comida

19 DIESTE, C. P. Las cocinas regionales. Principio y fundamento etnográfico. Ponencia para el VII Congreso Internacional de Sociología Rural. Quito, Ecuador 20-24 de noviembre de 2006. p. 1. (CD-Rom). A autora sistematiza, ademais, uma proposta interessante para um "guia de registros" das cozinhas regionais, apontando aspectos variados a serem observados, pensados em termos de padrões tradicionais e mudanças. Apresenta, ainda, propostas de análise dos riscos que afetam as "condições que propiciam e sustentam as cozinhas regionais", assim como propõe ações econômicas, educativas, políticas e de pesquisa e difusão, a exemplo de publicações, documentários e exposições museológicas e fotográficas.

20 Em Minas e Goiás chamam-se quitandas os pães de queijo, os biscoitos de polvilho, os bolos, as roscas, as broas e demais guloseimas, servidos como lanches ou cafés da manhã.

21 Sobre a comida consumida no dia a dia, em casa, remetemos ao nosso livro ABDALA, op. cit., 2007a. Nos restaurantes: ABDALA, M. C. Mesas de Minas: as famílias vão ao self-service. Tese (Doutorado em Sociologia) - Faculdade de Filosofia, Letras e Ciências Humanas, Universidade de São Paulo, São Paulo, 2003. 
cotidiana das famílias estudadas. Não foram mencionadas participações em feiras, como as observadas em Minas. Também não havia restaurantes caseiros e pontos de comercialização de produtos como queijos, requeijões, farinha, polvilho e doces por se tratar, na grande maioria, de pessoas que ainda habitavam áreas rurais e realizavam as vendas de modo informal. A exceção foi a comercialização de cachaça.

A discussão será estruturada em quatro partes, levando-se em consideração a diferença dos dados coletados nas duas regiões, acima apontada. Inicia-se pelas memórias de práticas que não ocorrem mais ou estão em declínio e, em seguida, serão tratadas as festas religiosas, as feiras, a produção artesanal e o pequeno comércio, enquanto manifestações que ocorrem no domínio público. Finalizando, serão abordados os hábitos cotidianos, com ênfase no consumo doméstico e nas classificações dos alimentos.

\section{Saborosas memórias}

Nas memórias coletadas no sudeste goiano destacaram-se, de modo especial, os relatos sobre a antiga prática de mutirões ou traições nas comunidades rurais. Momentos de solidariedade vicinal e trabalho coletivo que associavam ajuda mútua à alegria e à cantoria e, ao final do trabalho, ocorriam as festas chamadas de brincadeiras, forrós ou pagodes e muita comilança ${ }^{22}$. Desta forma, foi possível perceber a importância da

22 Sobre os mutirões, temos o estudo clássico de CANDIDO, Antonio. Os parceiros do rio Bonito. São Paulo: Livraria Duas Cidades, 1982. Ver também Sílvio Romero: “Outro ensejo para apreciar-se a evolução da poesia popular é observar o povo no seu trabalho [...] O povo, em verdade, deve de preferência ser observado na sua laboriosa luta pela vida [...] Ele então canta, e o seu cantar é másculo e sadio [...] Entre nós temo-lo observado por vezes. Ou nos grandes eitos lavrando a terra, ou deitando matas ao chão, ou nos engenhos no moer das canas e na preparação do açúcar, sempre o trabalhador vai cantando e improvisando. É o cantar elogio ou cantar ao desafio, expressões de alegria usadas em Pernambuco. Em Sergipe chamam arrazoar ao cantar versos de improviso [...] um roceiro, que tem um serviço atrasado, roçagem, plantação ou colheita, convida os vizinhos para o ajudarem a levar avante o eito; acedendo estes, forma-se o que chamam no Rio de Janeiro potirão... dura às vezes dois e três dias. É um trabalhar livre e galhofeiro ao som de cantigas. Também o fazem para tapagens de casas, e as mulheres o empregam na fiagem do algodão. Trabalha-se, bebe-se e canta-se. Isto é nas populações agrícolas das matas; nas criadoras dos sertões observam-se os mesmos costumes com as indispensáveis alterações." ROMERO, Sílvio. Cantos populares do Brasil. Introdução. [Dados de edição indisponíveis]. Disponível em: <http://pt.wikisource. org/wiki/Cantos_populares_do_Brasil/Introdu\%C3\%A7\% C3\%A3o>. Acesso em: nov. 2009. 
prática como fator de reforço dos laços sociais entre vizinhos e parentes nos municípios estudados ${ }^{23}$.

A entrevista de Dona Olívia de Sá Vieira, de Campo Alegre-GO, desvela esse universo que associava trabalho, festa e diversão:

[...] quando o povo reunia nas casas, fazia os mutirão que eles falam, né? Lá na fazenda eles convidavam a vizinhança toda pra ir, tal dia assim, assim, dia cinco, dia dez, cê vai lá em casa pra gente fazer um mutirão, vai fiar, vai bater pasto...

[...] ficava o dia todo, fazia almoço, fazia janta, fazia tudo lá.

E depois fazia um festão!

[...] É, matava vaca, porco, matava frango e nem usava macarrão... era mandioca, era essas coisas assim, num tinha muita coisa não...

[...] era bom demais, menina! Nossa! ${ }^{24}$

A comida simples, mas farta, contava apenas com os recursos dos quais o grupo dispunha. E, como observa Araújo (2010), quando a falta desses constituía possível impedimento para a realização do mutirão, a ajuda vinha de surpresa, a "traição" ou "treição". Dona Helena Rosa de Mesquita explica:

[...] traição era assim, o pessoal da casa não sabia, então quando chegava a noite, ia todo mundo para lá, passava a noite inteira dançando, ainda ficava lá, já ia trabalhar no outro dia, e ainda emendava a outra noite também dançando. Era o dia inteiro farra e a noite também ${ }^{25}$.

23 Sobre mutirões na região do sudeste goiano: ARAÚJO, Daniel S. Sociabilidade e vizinhança nas comunidades rurais às margens do Rio São Marcos: permanências e mudanças. Trabalho de Conclusão de Curso (Graduação em Ciências Sociais) - Universidade Federal de Uberlândia, Uberlândia, 2010; SANTOS, Márcia Pereira dos. O campo (re)inventado: transformações da cultura popular rural no sudeste goiano (1950-1990). Dissertação (Mestrado em História) - Universidade Federal de Uberlândia, Uberlândia, 2001.

24 VIEIRA, Olívia de Sá. Depoimento. Campo Alegre de Goiás, jan. 2009.

25 MESQUITA, Helena Rosa de. Depoimento. Comunidade Varão, Davinópolis, jan. 2009. 
No momento da pesquisa mutirões e traições praticamente não ocorriam mais. As explicações dadas foram as mudanças que há longos anos vêm atingindo o campo. Muitos foram embora para a cidade, expulsos pelas monoculturas, como a da soja, destinadas ao mercado global; pela criação intensiva do gado; pelo desinteresse dos jovens em continuar os projetos dos pais, pequenos agricultores familiares, uma vez que seus projetos de futuro são fundados no sonho do progresso e do sucesso na vida urbana.

A mesada dos inocentes, como as demais festas religiosas que encontramos na região afetada pela construção da Usina, foi exemplo de fé que incorporava a refeição partilhada, uma espécie de comunhão, de símbolo da ceia sagrada. Permanece viva na memória de Dona Divina Aparecida Corinto, mas praticamente não é mais realizada, pois, de acordo com ela, as crenças também foram mudando:

É assim uma pessoa doente, um incômodo assim incurável vamos dizer, né? Um incômodo, aí faz uma tensão [intenção]... pega um santo, São Sebastião, Nossa Senhora Aparecida se aquela pessoa for curada, sarada do incômodo [...] E depois faz uma mesada para os inocentes, uma janta, os inocentes tudo jantando, tá vendo? Então, meu marido era muito religioso, aí celebrando missa em nossa casa, terça o altar das reuniões na nossa casa, tá vendo? A mesada dos inocentes. Aí, convidam os vizinhos, as criancinhas de sete anos abaixo [...] é só eles que comem, sabe assim naquela mesada. Aí quando a pessoa é atendida pelo aquele pedido vai cumprir a promessa [...] Hoje em dia o povo tá muito diferente, né? Mas tem alguém que às vezes ainda faz, mas eu não tou sabendo não, que hoje o povo tá, não tem essas crenças mais fala que isso é bobagem ${ }^{26}$.

A malhação de Judas é outra prática em declínio às margens do rio São $\operatorname{Marcos}^{27}$. Nas falas dos entrevistados(as), a participação das comunidades foi apontada como fundamental, tanto nas doações para a festa como

26 CORINTO, Divina Aparecida. Depoimento. Catalão, fev. 2009.

27 Um dos motivos do declínio foi a falta de apoio da Igreja, que condena o ato de violência ao boneco, em nome do perdão cristão. Além disso, a conotação política que a queima do Judas vinha assumindo, com os bonecos sendo feitos à semelhança de políticos corruptos malhados pelo povo, também inspirou cuidados por parte da Igreja. 
na sua preparação. Sr. José Rodrigues Martins, o Zé do Retiro ${ }^{28}$, lembrou que o percurso feito carregando o Judas para o pedido dos alimentos era momento marcante da diversão, que não se limitava à queima do boneco. Roubar frangos fazia parte da tradição, como lembram algumas pessoas. Como forma de brincadeira, roubavam dos próprios participantes ou daquelas pessoas que se recusavam a fazer doações. A farofa de frango, receita “típica” da região, não faltava na madrugada de sábado, preparada após a meia-noite, quando terminava o jejum da sexta-feira da Paixão, seguido de festa que durava até o dia amanhecer. Hoje a farofa é presença constante nas rodadas de truco. Dona Sebastiana Miguel da Silva explicou como é preparada: "Põe pra cozinhar a galinha [inteira] aí quando ela tá cozida [...] aí desfia tudo e frita e joga a farinha [de mandioca ou de milho]"29.

\section{As festas religiosas}

Várias festividades associaram divertimento e mesas fartas, unindo sagrado e profano, momentos por excelência de devoção e intenso preparo coletivo para sua realização. Nas cidades mineiras estudadas, destacaram-se as folias de reis e congadas. No sudeste goiano, além dessas, nos deparamos com a folia do Divino, a folia de São Sebastião, as festas juninas, as chamadas "festas de roça" e tantas outras que reuniam centenas de pessoas em nome da fé, propiciando ao mesmo tempo formas de encontro coletivo.

Nos vários festejos populares registrados nas duas regiões observadas, a comida é ponto fundamental nos rituais: da festividade de São João à moda antiga, passando pelas folias de Santos Reis até a Congada. O aspecto que chama a atenção é a preparação nos bastidores, tanto em Minas como em Goiás. São numerosos os registros dos dias de festividades aos santos de devoção, das celebrações, dos rituais, das procissões. No entanto, pouco se tem documentado o processo de preparação desses festejos, que muitas vezes duram meses e que têm nas ceias espaços privilegiados de reforço

28 MARTINS, José Rodrigues. Depoimento. Fazenda Pires, Catalão, fev. 2009.

29 SILVA, Sebastiana Miguel da. Depoimento. Campo Alegre de Goiás, Comunidade Rancharia, jan. 2009. 
das tradições ancestrais e dos laços sociais. É notável a generosidade dos devotos e foliões nas mais diversas folias que presenciamos. Para que a ceia seja realizada, como ocasião de partilha e de comunhão, as doações envolvem esforços coletivos de todas as pessoas que têm fé em algum dos santos comemorados. Como observa Araújo: “[...] há por vezes que alterar a rotina do trabalho, dedicando-se apenas àquelas atividades inadiáveis, para respeitar as obrigações do dia santo". Ele destaca também o revezamento entre os membros da comunidade para assumir as responsabilidades das festas $^{30}$. Novilhas, leitões, frangos e galinhas são engordados ao longo do ano e doces são preparados e armazenados. Mesmo as mais humildes casas recebem os foliões com quitandas, doces ou até um pão com carne moída, mas todos retribuem a passagem daqueles que trazem as bandeiras com hospitalidade e a simbólica partilha do pão ${ }^{31}$.

Na Folia do Divino Espírito Santo, no mês de julho, em Campo Alegre de Goiás, dona Antônia Guimarães, ao longo dos anos, mantém o ritual de acender seu forno de barro para preparar receitas tradicionais de família, que serve àqueles que acompanham o giro dos foliões: o biscoito de coalhada assado na folha de bananeira, os pães de queijo, as petas - biscoitos de polvilho feitos com banha -, o mané pelado (bolo feito de massa de mandioca) e o café quentinho e perfumado, que muitas pessoas na região ainda torram e moem na hora.

As refeições servidas durante as folias têm um cardápio que conserva bastante as tradições, semelhante nas duas áreas observadas, onde se destacam as almôndegas ou "pelotas" fritas. Além dessas, há sempre mais de uma carne, geralmente frango frito ou ao molho, arroz, feijão, mandioca cozida e macarrão. Esses pratos não faltam. O macarrão com frango ao molho aparece nas duas regiões. Em Minas a mandioca é cozida sem tempero, quando muito com sal. Em Goiás ela é servida temperada, com cebola, sal e cheiro-verde. Carne de porco ou de vaca em pedaços e frita também é bastante comum. $\mathrm{O}$ feijão tropeiro não falta na mesa goiana, enquanto em Minas é mais comum feito em caldo ou tutu. Inovações aparecem nas duas regiões, como saladas de legumes cozidos ou carnes com batatas.

30 ARAÚJO, D. S. Op. cit., p. 33.

31 Alguns relatos citam sanduíches de pão com carne e cachorros-quentes que são servidos nessas ocasiões, embora menos frequentes, pois parecem menos valorizados. "[...] aqueles que não têm condições de servir um lanche melhor servem pão com carne, arroz doce, canjica”, mas ninguém que recebe a visita da bandeira deixa de servir algo. Conforme depoimento colhido em Campo Alegre, jul. 2009. 
Quanto aos doces, o de leite e o de mamão verde feito em pedaços, em tiras ou ralado são os campeões nas duas regiões. Também são citados outros preparados com frutas, como os de casca de laranja e de limão, goiaba, manga, figo, caule de mamão ralado, mamão ralado com leite. Além desses, em Minas o de abóbora também é comumente servido.

Nas festas "de roça" goianas, o cardápio do almoço comunitário servido no último dia é praticamente o mesmo das folias: arroz, feijão ou tutu de feijão, frango ao molho, pelotas, macarronada e mandioca. Na mesa de doces, igualmente são servidas as mesmas variedades, mas também foram citados os pés de moleque (doces secos feitos de amendoim com rapadura e leite) e as "ameixas de queijo" (doces em calda feitos com ovos e queijos em formato de pequenas bolas enfeitadas com um cravo).

Os leilões são comuns em várias festas do sudeste goiano, como as congadas, as folias, as "de roça". Além dos tradicionais frangos, linguiças e leitoas ou pernis assados, as bandejas podem trazer salgados, como empadas de massa fina, coxinhas e pastéis. Também é comum doar carnes não preparadas ou animais vivos. Nas festanças "de roça", a ceia coletiva se restringe ao último dia. As bandejas leiloadas e algumas barracas vendendo comidas constituem as opções de alimentação nos demais dias.

Leilões com animais vivos e bandejas de frangos, leitoas e pernis assados também são comuns nas folias e nas congadas em Minas. Nessas últimas, vale qualquer produto para arrecadar donativos, inclusive gêneros industrializados, como pacotes de macarrão, garrafas de vinho ou cachaça, dentre outros que pudemos observar na cidade de Uberlândia.

Alguns dos foliões se queixam que a tradição das mesas de doces está acabando. Embora nas Folias de Reis de Araxá e Uberlândia a grande quantidade desses ainda seja uma realidade, em Frutal-MG, um de nossos entrevistados disse que em outros tempos a fartura era maior e que, nos dias atuais, muitas festas de Folia de Reis na cidade não os servem mais. $\mathrm{Na}$ região de Davinópolis-GO, lembrada pela presença marcante dessas mesas nas festividades, também ocorreram mudanças nesse aspecto, como aponta dona Julita Martins dos Santos:

Antigamente as festas aqui era de doce... Antigamente, no dia da festa tinha que dá doce [...] Agora eles dá, assim, a comida mesmo pras pessoas, né? Comida de sal. Dá doce mais num é aquela tradição de tanto de doce que fazia não [...] Antigamente 
punha uma mesa... fazia um rancho, uma barraca e punha a mesa e todo mundo comia.... ${ }^{32}$

Comemorações juninas de tipo mais tradicional, voltadas para a devoção aos santos do mês e contando com a realização de terços, alguns deles cantados, ainda ocorrem em várias comunidades da zona rural do sudeste goiano. Documentamos a festa de São João, na Fazenda Pires, município de Catalão, realizada por dona Maria Helena Ferreira, que há mais de vinte anos promove um terço cantado em cumprimento a uma promessa. As orações e a fé são centrais, mas uma farta refeição é servida aos convidados: arroz com pequi (este é congelado para a ocasião), arroz com guariroba, caldos de traíra, de feijão e de frango e o especial mané pelado assado na folha de bananeira são realçados entre vários doces e pratos salgados. O pé de moleque e pratos feitos à base de milho, como as pamonhas, são tradicionais nos festejos do mês.

Outra celebração junina tradicional registrada foi em Ituiutaba-MG. Sr. José Pereira Borges ${ }^{33}$ trouxe da "roça" o hábito de rezar o terço para São João. Desde os anos 1940 reúne amigos, vizinhos e familiares no quintal de sua casa, acende a fogueira, hasteia a bandeira e nada de shows, fantasias, danças ou quadrilhas. É só o terço e o hábito de servir uma quitanda, pipoca e café depois da reza. Amigos e familiares comungam esse momento patrocinado pela persistência da fé e do cumprimento da promessa desse patriarca quase centenário.

Registramos também as Congadas em louvor a Nossa Senhora do Rosário e São Benedito e sua importante força de mobilização dos fiéis nas duas áreas pesquisadas. Ao longo do ano, faltando aproximadamente quarenta dias para a comemoração, cuja data pode variar nas cidades observadas, são realizados leilões e visitas em residências dos devotos angariando recursos. Em Minas, a duração da festa varia de um a dois dias, em que almoços reúnem os ternos ${ }^{34}$ e seus convidados de outras cidades. $\mathrm{O}$

32 SANTOS, Julita Martins dos. Depoimento. Davinópolis, jan. 2009.

33 BORGES, José Pereira. Depoimento. Ituiutaba, fev. 2007.

34 Os numerosos grupos que participam da Congada recebem a denominação de Ternos de Congos e de Moçambiques. Tais grupos são identificados por tipos específicos de canto, percussões e vestuários, reunindo linhagens de família, amigos, vizinhos e devotos sob a liderança de um "capitão". Cf.: BRASILEIRO, Jeremias. Cultura afro-brasileira na escola. O congado em sala de aula. Uberlândia: Ed. Aline, 2009. p. 11. 
cardápio comporta o habitual arroz com feijão acompanhado de frango ou carne de panela, macarronada (macarrão ao molho de tomate) e mandioca. No almoço de alguns grupos em Uberlândia, a costela de vaca com mandioca - a vaca atolada - tornou-se tradição. Em Araxá, há participantes que servem canjiquinha com ora-pro-nóbis e feijão com pé de porco ou mocotó de vaca, para fortalecer os congadeiros ${ }^{35}$. Para os ternos, o ritual revivido a cada ano é momento privilegiado de confraternização.

É interessante notar, na congada de Catalão, que a participação de pessoas da comunidade sírio-libanesa como festeiras, desde 1950, trouxe a incorporação de sua culinária. Durante os festejos, que duram nove dias ${ }^{36}$, no primeiro dia serve-se uma mesa de quibes, esfirras, charutos, arroz com lentilha. A venda de espetinhos nas redondezas da festa também incorporou definitivamente a influência de gaúchos, com o consumo da carne assada.

Para aqueles que organizam todas essas festividades, elas representam momentos de vivenciar a tradição, possibilitados pelos rituais da fé. As preparações da comida, do presépio, dos enfeites, dos arcos decorados por onde passam as procissões conservam procedimentos tradicionais e $\mathrm{o}$ significado que as orienta é a devoção. Por onde passam, as folias simbolizam o percurso dos reis magos, promovendo o encontro, a solidariedade, o reviver a fé cristã. A esse respeito, é significativo o depoimento de dona Sueli de Fátima Mamede, de Uberlândia:

Tem assim muita união de todo mundo, todo mundo é muito unido, igual ce vê, tem muita gente, todo mundo trabalha. Igual esses que tá aqui trabalhano, eles vêm de São Paulo, todo ano eles vêm, esses menino [...] Eles faz de tudo, eles lava tacho...

[...] Tem muito significado, é muita fé neles [Santos Reis] $]^{37}$.

Nas tarefas necessárias ao bom andamento da celebração, homens e mulheres participam, muitas vezes rompendo a divisão de trabalho tradicional no âmbito doméstico. Não é raro ver homens nas cozinhas, temperando

35 SILVA, Irani Antônia da. Depoimento. Araxá, jan. 2007.

36 Durante os nove dias de festa ocorrem as ceias, mas os ternos só saem no primeiro e nos três últimos dias.

37 MAMEDE, Sueli de Fátima. Depoimento. Uberlândia, Fazenda Mata dos Dias, distrito de Martinésia, jan. 2007. 
almôndegas, fazendo comida e mexendo as grandes panelas nas fornalhas. Nas procissões e grupos de foliões, em que sempre houve praticamente exclusividade da presença masculina, cresce o número de mulheres que puxam as rezas e as cantorias, que levam as bandeiras dos santos e assumem o papel de festeiras, responsáveis pela organização geral do evento.

Nos últimos anos notam-se algumas mudanças durante os dias das comemorações. À exceção da Folia do Divino, em Goiás, que ainda conta com cavaleiros e amazonas que peregrinam na zona rural e na cidade, os giros não são mais feitos a pé ou a cavalo. Muitas vezes motos e caminhões transportam os foliões e os celulares avisam sua chegada nas casas que os receberão. Nas cidades e mesmo em algumas comunidades rurais, duplas sertanejas são contratadas para os bailes, a mídia documenta tudo, turistas e centenas de pessoas são atraídos pela festança e fartura, mas nem sempre pela fé, como observou Sr. Antônio Sousa: "Aumentô muito. [...] o tanto de gente qui vem de Uberlândia [...] Num é totalmente, mas a maior parte é pela comida, que as comida são boas $[. .$.$] na hora do terço mesmo acontece$ de ter poucas pessoa..." ${ }^{38}$

Reuniões mensais com finalidade religiosa, no âmbito das comunidades, também foram narradas. Não chegam a ser propriamente festas. Os católicos da fazenda Rancharia se reúnem no primeiro domingo do mês para celebração de missa ou para rezar o terço. Em seguida, servem um almoço - que consiste em churrasco com mandioca, salada ou vinagrete, tutu e arroz - ou um lanche, com quitandas e café. É comum nessas ocasiões acontecerem rodadas de truco. Os evangélicos realizam um encontro uma vez por mês para orar, recebendo constantemente pessoas de outras comunidades, como foi descrito em Davinópolis. Servem o que denominam de ceia, com suco de uva e quitandas, após as orações. Desta forma, fica evidente que, nesses momentos de reunião propiciados pela fé, reforçam-se laços sociais, de amizade e de pertencimento e que o alimento é "fulcro de sociabilidade", na expressão que retomamos de Candido (1982). 


\section{Feiras, produção artesanal e pequeno comércio}

Continuamos nosso percurso no âmbito público, analisando o comércio de alimentos preparados de acordo com procedimentos tradicionais relativos aos saberes herdados durante gerações. Nesse aspecto, é bastante comum a interferência de agentes de órgãos públicos introduzindo preceitos de higiene, qualidade e saúde. Em Minas, ficou clara a tensão entre os saberes ancestrais e os novos procedimentos exigidos, mas concessões são feitas por parte daqueles que se dispõem a colocar seus produtos no mercado, como foi observado nas feiras promovidas pela EMATER para pequenos produtores ou mesmo nas feiras livres. Fazem-se os cursos preparatórios, incorporando novos procedimentos e exigências, assim como as reformas requisitadas nos locais de produção dos alimentos ou nas embalagens - os plásticos envolvendo os doces antes de serem enrolados na palha de milho seca, as numerosas informações que devem constar nos rótulos de muitos desses produtos, dentre outras. No entanto, se reconhece que não é possível abrir mão de alguns conhecimentos adquiridos, pois se observa que leite e polvilho da fazenda, ovos caipiras e banha fazem a diferença nesse comércio e que doce bom tem de ser feito em tacho de cobre. Compra-se o fogão a gás para ajudar no aumento da produção, mas considera-se que a broa de fubá, o mané pelado, o queijo e o requeijão, a geleia de mocotó, a farinha, se não são feitos no fogão a lenha, "não pegam cor", "não ficam a mesma coisa". Dessa forma, mantêm-se centenárias receitas de famílias, modos de fazer e saberes tradicionais, que não podem ser imitados pela indústria.

A maioria dos feirantes sai ainda de madrugada da zona rural. Nas feiras, encontram mais do que o meio de ganhar o pão. Importam o convívio, as amizades adquiridas, os fregueses que depois de anos permanecem fiéis, as encomendas que chegam de longe. $\mathrm{O}$ burburinho desses lugares de encontros, mais que espaços de compra e venda, contrasta com o espaço exuberante e comportado do supermercado. Há um prazer em comprar sentindo-se alguém especial, não um simples "cliente". Ou mesmo o prazer de jogar "conversa fora".

Nas andanças pelas feiras, mercados e pontos de venda especializados em produtos artesanais e "da roça", nas cidades mineiras, encontra-se uma variedade de artigos que vêm direto do campo, como rapadura e melado; queijo de trança ou de cabaça; requeijão branco ou moreno, de cortar; goiabada; licor de jenipapo, de murici e muitos mais. Uma ampla gama de doces: 
mamão, figo, pêssego verde, goiaba, jenipapo, caju e até cajuzinhos do campo (cajus bem pequenos, de uma planta arbustiva que cresce no cerrado e está ameaçada de extinção). Quitandas como broa de fubá, biscoitos de polvilho e o mané pelado (bolo de mandioca) com aquela crosta negra do fogão a lenha, e o pau-a-pique (massa de mandioca com ovos e melado assada na folha de bananeira). A geleia de mocotó de consistência firme, aroma de canela, que o desavisado confunde com barra de doce de leite "de cortar", é herança das fazendas do Triângulo Mineiro. Há também as farinhas de milho e mandioca fresquinhas, recém-torradas na fornalha a lenha, em tachos de cobre; algumas são temperadas, mas só com toucinho, cebola e sal, nada de temperos químicos! Pamonha feita na hora, de sal e de doce; café da fazenda, torrado e moído na hora; ovos e frangos caipiras; guariroba; garapa. Vez por outra escapa um doce de leite ou pingo de leite na palha, sem o plástico asséptico!

Além das feiras, notou-se um número crescente de pessoas, predominando as mulheres, que fazem do aprendizado doméstico um "ganha-pão". Muitas fornecem produtos artesanais para mercados e supermercados ou abrem lojas para vendê-los. Em Minas, os pontos comerciais especializados em quitandas são as chamadas quitandas caseiras, e em Goiás as biscoitarias. As receitas aprendidas nos cadernos presenteados pelas avós, obrigatórios nos enxovais, transformaram-se em mercadorias atrativas, pois a praticidade da vida doméstica contemporânea impõe o hábito de "comprar pronto", que substitui o de fazer em casa. Assim, a broa de massa de queijo, o biscoito e o pão de queijo, as variadas receitas de biscoitos de polvilho doce e azedo, a multiplicidade de bolos, licores e compotas de frutas, geleias, doces de leite representam possibilidades econômicas para aquelas pessoas que têm o sustento associado ao seu conhecimento ancestral.

Iniciativas familiares em que proprietários e proprietárias trabalham na cozinha e nos serviços, à beira de um fogão a lenha, também são partes desse processo que descrevemos. Algumas donas de casa abrem suas residências e servem a mesma comida "caseira" que alimenta suas próprias famílias, enquanto outras se transferem para locais separados da casa. Ambas as situações atraem uma clientela crescente que tem essa comida como referência identitária e reapropria o espaço do restaurante como se fosse o da própria casa. Assim, o que se nota nesses restaurantes são a rusticidade e a simplicidade da comida e do ambiente, que, longe de afastarem os clientes, reforçam o atrativo do lugar. 


\section{O estabelecimento de dona Terezinha Ferreira, em Patos de Minas, é exemplar nesse sentido:}

Eu comecei a fazê pros meus fios, é pra nóis mesmo [...] Aí o povo foi chegano [...] Aí num tem uma praca, num tem um nome, senhora tá veno, aí num tem nada, mas o povo gosta de vim [...] Aí senhora tá veno a cumida é feita simpres mais cum amor e carinho. Do jeito que eu faço a cumida pros meus fio eu faço pa fio de todo mundo [...] é no fugão de lenha [...] Aqui tem de tudo [...] A cumida daqui é cumida casera, num tem nada diferente, um prato diferente [...] Agora eu acho que o povo qué é liberdade [...] Vai lá e põe do jeito qui eles qué, agora se eles qué qui passa um ovo, eles fala [...] Tempero é eu qui faço [...] aio, a pimenta e o sal. É nóis é qui faiz, num usa tempero de ninguém não. [...] Açafrão usa no frango ${ }^{39}$.

Assim como esse restaurante, outros pequenos estabelecimentos que também servem a comida no fogão a lenha, já separados do espaço da casa, podem ser encontrados nas cidades estudadas. As comidas diárias são, como as de dona Terezinha, aquelas que geralmente considera-se "caseiras e típicas": arroz, feijão, tutu ou feijão tropeiro, milho refogado ou angu, mandioca cozida, podendo ser com ou sem carne, mandioca frita, banana-da-terra frita, bolinhos de arroz, abobrinha "batidinha" (bate-se a faca de modo a formar pequenos pedaços, semelhantes ao ralado), verduras variadas como chuchu, abóbora, quiabo, jiló em forma de $\operatorname{molhos}^{40}$, cará, carnes de porco ou vaca fritas - carnes de panela -, bifes, almôndegas, linguiças suínas, torresmos, frango frito ou ao molho, ovos fritos, macarrão com molho de extrato de tomate e farofas variadas, incluindo as de abobrinha e jiló. São poucas as opções de salada, praticamente tomate, cenoura e alface. Nos finais de semana pode haver alguma variedade a mais, como carnes assadas e lasanha ${ }^{41}$.

39 FERREIRA, Terezinha. Depoimento. Patos de Minas, mar. 2007. Ela tem mais de 80 anos e trabalha com duas filhas.

40 São chamados molhos os preparos com legumes ou pequis refogados e cozidos de modo a juntar um caldo.

41 Vale notar que nas regiões do Triângulo Mineiro e Alto Paranaíba, nos últimos anos, ocorreu um significativo patrocínio do chamado turismo rural, com multiplicação do número de restaurantes que servem a comida considerada caseira e "típica", disposta em fogões a lenha. Alguns desses locais são 
Por certo há explicações para o crescimento desses tipos de comércio, como já apontáramos em artigo anterior ${ }^{42}$. A precarização das condições de trabalho e o aumento do desemprego ampliam a informalidade, fundada no trabalho familiar, com predominância da mão de obra feminina. Além disso, ocorre crescente terceirização de atividades do âmbito doméstico, propiciada pelo aumento da inserção da mulher no mercado de trabalho - a exemplo dos atos de cozinhar, lavar e passar roupas -, e pela redução do emprego doméstico devido às crescentes exigências trabalhistas e ao próprio desinteresse das mulheres pelas tarefas do lar, que atinge tanto empregadas quanto patroas ${ }^{43}$. Além disso, a valorização do local e do tradicional cresce com a tendência à homogeneização de hábitos alimentares e culturais em escala mundial, o que pode suscitar tanto um renascimento da localidade quanto uma globalização da etnicidade ${ }^{44}$.

A cachaça também mostra uma trajetória de adequação nos modos de produzir, como ocorre nos casos dos doces e das quitandas. É uma bebida de origem popular, que no período colonial destinava-se ao abastecimento de escravos e animais. Embora ainda existam alambiques voltados apenas ao consumo doméstico ou à venda clandestina - realidade que durou mais de um século, durante o período de extração mineradora no séc. XVIII -, há uma tendência ao aperfeiçoamento e investimento em qualidade por parte de um número significativo de fabricantes. Investe-se em aprimorar a produção artesanal, resultando numa bebida melhor e, consequentemente, ocorre ampliação do consumo, embora o preço seja maior do que aquele das bebidas tradicionalmente consumidas em vendas e botecos, muitas vezes de baixa qualidade ${ }^{45}$.

Algumas marcas se tornaram reconhecidas no mercado, como a premiada "Bendito Grau", de Patrocínio-MG e a "Castelo Branco", de

fora das cidades e costumam abrir apenas aos finais de semana. Em geral, dispõem de maior variedade de opções, entre elas leitoas e pernis assados, frango assado ou ao molho pardo, lasanha, peixes e variedade de saladas. Outros introduziram churrascos e carnes grelhadas.

42 ABDALA, M. C. Sabores da cultura popular: tradições e mudanças. In: MACHADO; ABDALA, Op. cit., 2007.

43 Ibidem.

44 ROBINS, K. Cultura global. In: HALL, Stuart. A questão da identidade cultural. 2. ed. Campinas, SP: UNICAMP, IFCH, fev. 1998. (Textos Didáticos, n. 18).

45 De acordo com Danilo Jaber Barbosa (cachaça "Bendito Grau"), essas cachaças e aguardentes de baixa qualidade costumam ser "desdobradas" - com acréscimo de água e açúcar. BARBOSA, D. J. Depoimento. Patrocínio, fev. 2007. 
Campo Alegre-GO. Ambas as marcas investem na produção orgânica, com rótulos que atendem a consumidores exigentes e não se importam em pagar mais caro por um produto diferenciado. O proprietário da "Castelo Branco", senhor Luis Manteiga, nos deu um depoimento que aponta as mudanças realizadas no decorrer dos anos e as conquistas alcançadas:

O engenho iniciou-se com aquele engenho antigo... funcionava a animais, funcionava a boi [...] Tinha bois que trabalhavam duas horas, descansavam, punha mais quatro, trabalhava mais duas. Só que esse engenho rodava 24 horas. Papai tinha cinquenta bois, dois carros de boi puxando cana [...] Ele fazia também rapadura e açúcar mascavo, e não era pouquinha não, era bastante, ele produzia duzentos e cinquenta litros de cachaça por dia. Aí o pessoal vinha buscar aqui, num chegou nem a engarrafar nesse período.

[...] Quando eu assumi, busquei peças antigas lá de Minas e montei esse mais moderno. Aqui é tudo orgânico, desde a plantação de cana, do microclima, da qualidade da água e hoje é um nome de referência nacional. O controle é desde a plantação da cana até o envasamento, vendo pro Brasil inteiro. $\mathrm{O}$ engenho gera energia própria, inclusive pra carro "alcoomóvel", empregamos até 18, 20 pessoas, mas com a usina hidrelétrica, vamos ter que repensar, pra manter a qualidade, né?

[...] então o que precisa fazer é um trabalho de marketing... Qualidade nós temos ${ }^{46}$.

Também na região de Davinópolis há uma cooperativa de produtores de cachaça e os cooperados fizeram vários cursos para aperfeiçoar a produção e se adequar às exigências dos produtos por parte do governo. De acordo com o entrevistado João Julio da Silva, aproveitam todo o rejeito da produção de cachaça, o que é uma tendência nos engenhos pesquisados.

46 MANTEIGA, Luis. Depoimento. Campo Alegre de Goiás, Fazenda Pirapitinga dos Monteiro, jan. 2009. 


\section{Hábitos alimentares cotidianos}

A rotina alimentar das pequenas cidades e zona rural do sudeste de Goiás traz indícios de um padrão bastante conservador. Para o cotidiano das famílias, sobretudo quando a mãe está sozinha com os filhos e filhas ${ }^{47}$, a comida é bem simples: o arroz com feijão, alguma carne, predominando o frango, ovos, uma verdurinha da horta. É frequente o hábito de comer na varanda da casa da fazenda, num banco ou na mureta.

No menu do dia a dia e de visitas que aparecem de surpresa, também destacam-se o frango caipira "de molho" (feito no caldo da própria ave) acompanhado com angu de milho verde e o pequi, servido de diferentes formas - com arroz, com frango ou como molho; a carne suína ou a "carne cheia" (recheada), preparadas e conservadas na banha de porco - "carnes na lata" - e os torresmos. As verduras mais apreciadas são as das hortas, muito comuns nos quintais: a abóbora, o quiabo, o jiló, o chuchu, a abobrinha, a cenoura, a guariroba, o tomate, o pepino, a alface, dentre outras que crescem ao lado das variadas espécies medicinais. Mandioca, milho e suas respectivas farinhas são essenciais no cardápio diário, feitos de variadas formas: mandioca cozida com ou sem carne, milho cozido, refogado, no arroz com galinha, no frango ao molho, pamonhas, mingau (curau), bolos, dentre muitas outras preparações. Também é comum o consumo de conservas de jurubeba e de pimentas e o açafrão em pó (curcuma) preparados nas próprias casas. Este último, muito utilizado nos pratos locais, tinge de dourado o arroz, o frango, o macarrão com frango, as farofas, a guariroba e a mandioca.

O pequi merece relevo especial por ser, ao lado do frango, o campeão das citações quando moradores da região são questionados a respeito dos pratos considerados "típicos" do lugar. Além disso, representa um verdadeiro ritual de iniciação daqueles que chegam de outros Estados ou países, começando pelo estranhamento inicial e, aos poucos, com pequi ou com açafrão colorindo de amarelo o arroz e o frango, vai cativando aqueles que o degustam. $\mathrm{O}$ relato do senhor Vladimir Peres a esse respeito é exemplar:

47 No sudeste goiano, muitas mulheres moram nas cidades com filhos(as) enquanto os maridos se deslocam diariamente para o trabalho nas propriedades rurais. Há também situações em que, morando com a família na zona rural, o homem sai para trabalhar na roça ou com o gado e não retorna à casa para o almoço. 
[...] é interessante o pequi, quando $90 \%$ das pessoas que chegam aqui não gostam... o pessoal que trabalha aqui eles ensinaram, e hoje, vou te falar um japonês aqui, ele, se você quer deixar ele feliz, você leva um pequi...

[...] é um prato que quando a gente recebe os parentes que vem aqui, é o que a gente tenta achar é a gueroba [guariroba] e o pequi, o frango com pequi e o quiabo.

[...] A princípio não. Aí depois, o pequi vai conquistando pelo paladar, pelo cheiro aí, depois come. Eu particularmente quando, primeira vez que eu tive contato com pequi, não foi bom, espinhou. Eu falei: “nó!” Isso aqui não é..., mas depois... hoje é imprescindível ${ }^{48}$.

Arroz com galinha, a galinhada - que também pode ser feita com pequi ou com açafrão -, é preferencialmente comida de festa, de domingo ou de visitas, acompanhada de tutu de feijão e uma salada. O churrasco é presença certeira nos dias destinados a reuniões de oração como também nos encontros para um jogo de truco, um bom "papo", que, assim como a pescaria são as maiores diversões da zona rural. No que concerne a essa última, o aspecto do encontro e da partilha é de tal modo valorizado que se sobressai nos relatos, praticamente não sendo citados o consumo de peixes e os modos de preparo, embora estes façam parte da dieta local.

Nas visitas ou almoço de domingo também são elaboradas receitas especiais para a ocasião, dentre as citadas estão a lasanha da senhora Ana Paula Felipe; a gelatina ou a "Montanha Russa", torta doce gelada, de dona Laudicéia Mesquita dos Reis; e a abóbora com carne seca de dona Maria Conforte, inevitáveis diálogos com as novidades que vão sendo incorporadas ao cardápio tradicional.

Como se trata de uma região de criação de gado leiteiro, é habitual o fabrico de queijos. Não é raro degustar um deles, que acabou de ser preparado, ou mesmo um requeijão quentinho. Já o pão, muito apreciado, tem de ser comprado nas padarias das cidades e conservado por alguns dias. Assim, são as quitandas que compõem o café da manhã e o lanche da tarde; são servidas nas reuniões para terços e orações, às visitas ou du-

48 PERES, Vladimir V. Depoimento. Campo Alegre de Goiás, Projeto Paineiras (PRODECER), jan. 2009. 
rante as peregrinações das mais diversas folias de santos, como pudemos notar. O trivial é composto por bolos como o mané pelado, pães de queijo e variados biscoitos de polvilho ou "goma", como os biscoitos de queijo e uma infinidade de receitas com leite ou queijo, como o doce de "ameixa de queijo", o arroz doce e o doce de leite, que mesmo alguns dos homens declararam saber fazer.

É característica das comunidades rurais aproveitarem, nas inúmeras receitas, tudo que têm no quintal, como ovos, mandioca, milho, além do polvilho e do fubá feitos nas propriedades ou adquiridos de vizinhos. Há quem faça ainda a peta, que é o "biscoito de goma" assado na folha de bananeira no forno a lenha ou forno de barro, este em extinção. Também encontram-se especialidades de família, como o bolo de cará de dona Sebastiana Miguel da Silva, de Campo Alegre, e o "bolo cartucho", de dona Maria Crisóstemo Pereira, da região de Davinópolis, ambos feitos com fubá de arroz pilado.

No tempo em que era comum o uso de fornos de barro feitos de cupinzeiros abandonados ou do fogão a lenha, sábado era dia de fazer quitanda e deixar guardada em grandes latas para o consumo da semana, costume que "foi ficando pra trás", como lembra o senhor Alcides José da Silva, da fazenda Rancharia, em Campo Alegre de Goiás.

Hoje muitos desses fornos foram substituídos por equipamentos a gás ou elétricos e as pessoas se queixam que os assados não têm o mesmo sabor. No entanto, na zona rural toda casa tem seu fogão a lenha, ainda muito utilizado no dia a dia, onde se faz o café coado na hora, quentinho.

Além das quitandas, as pamonhas são bastante consumidas. As reuniões entre amigos e família à época da colheita do milho, as "pamonhadas", ainda são costumeiras. As receitas variam pouco, podendo ser de sal ou de doce. Algumas se tornaram tradicionais, como a de dona Arminda Rosa da Silva, em Catalão, que mantém por mais de setenta anos o costume. Normalmente são cozidas na palha do milho, mas a singularidade de dona Arminda é que também faz pamonhas cozidas em folha de bananeira.

Licores e geleias, quando citados, propiciaram observar a relação que existe entre sua confecção e o contato com as agências governamentais que atuam na região com vistas à sustentabilidade e recuperação de tradições, ao mesmo tempo em que buscam adequação às exigências de higiene e qualidade. Assim, dona Nilda de Paula Pontes, moradora de uma fazenda no município de Catalão, relatou os cursos que fez no SENAC e 
as receitas que aprendeu. Ela explica em detalhes os procedimentos e sua duração, quantidades dos ingredientes e vasilhames utilizados. Em sua fala, no entanto, percebe-se o conhecimento tradicional quando diferencia o modo de fazer local, a que chamam vinho - com a fruta apenas curtida na pinga -, daquele com o caldo de jabuticaba fervido. A mesma diferença pode ser observada na explicação de dona Divina Dias Canedo, da fazenda Rancharia, em Campo Alegre:

[...] da jabuticaba nóis faiz mais é vinho.

É licor, nóis fala vinho...

[...] nóis faiz assim: nóis coloca... tira a semente dela e coloca ela de molho num pouquinho de álcool [pinga], muito pouquinho, sabe? E deixa muitos dia, depois nóis coa e faiz e coloca um pouquinho de açúcar e tá o licor pronto e gostoso!

[...] ai já é curtido, não é cozido não. Muita gente diz que faiz ele fervido eu nunca fiz ${ }^{49}$.

Todavia, se aprendizados e inovações são percebidos, chamam a atenção preceitos alimentares transmitidos há várias gerações, expressos ao relatar costumes relativos a noções do que é saudável, às classificações de alimentos e aos tabus ${ }^{50}$.

Nesse ponto, a banha de porco se destaca por ser componente histórico da alimentação cotidiana, sobretudo na zona rural, e elemento central do gosto local. Esta se torna alvo privilegiado do confronto entre o saber médico, que em geral a condena como prejudicial à saúde, e o que se observa na experiência vivida. O senhor Sebastião Eurípedes Inácio expressa bem a questão:

2009.

49 CANEDO, Divina Dias. Depoimento. Campo Alegre de Goiás, Fazenda Rancharia, jan.

50 A respeito de tabus alimentares em Goiás, consultar: BRANDÃO, Carlos Rodrigues. Plantar, colher, comer: um estudo sobre o campesinato goiano. Rio de Janeiro: Graal, 1981; ORTENCIO, Bariani. Cozinha goiana: estudo e receituário. 2. ed. Goiânia: Oriente, 1981. Sobre tabus brasileiros e em Minas, ver também CASCUDO, Câmara. História da alimentação no Brasil. Belo Horizonte: Itatiaia: Edusp, 1983; ABDALA, M. C. Op. cit., 2007a. 
Mudou bastante. [a comida] mudou bastante mesmo.

Ontem nós estávamos comentando isso: de primeiro criava porco, matava [...] fazia aquele tipo de prancha, né? Fazia aquelas paneladas de mandioca cozida, né? Minha mãe comia... minha mãe durou noventa e tantos anos, quase cem anos. E ela comia feijão, por exemplo, aquele toucinho gordo do feijão, cê sabe? Aquilo comia quase todo $\mathrm{dia}^{51}$.

Quanto aos tabus relativos às classificações dos alimentos e a misturas que devem ser evitadas, foram ressaltados os relativos à comida considerada "quente" 52 , como porco e manga, que podem fazer mal para determinadas enfermidades e nesses casos devem ser evitados. No que concerne às misturas tidas como inadequadas, aquelas com mangas e com ovos são as mais citadas. O senhor José Gonçalves de Mesquita nos dá numerosos exemplos a esse respeito:

Ah, diversos trem não podia, se ocê comesse manga não podia leite [...] se almoçasse não podia chupar cana, fazia mal... isso assim era diversas coisa que não podia misturar. E hoje o povo come de tudo, faz qualquer misturera e nem...

[...] Antigamente, se o cara comesse pepino não podia comer ovo também [...] come ovo não podia beber pinga, bebesse pinga não podia comer manga, hoje eles tira gosto de uma taia de manga com um copo de pinga. (risos) $)^{53}$

As restrições da dieta pós-parto são recorrentes nos preceitos populares. Dona Sebastiana Miguel da Silva, da Fazenda Rancharia, em Campo Alegre de Goiás, é referência na região quando se aborda esse tema,

jan. 2009

51 INÁCIO, Sebastião Eurípedes. Depoimento. Campo Alegre de Goiás, Fazenda Rancharia,

52 "Os alimentos em geral são classificados pelas populações que os consomem em quentes ou frios, fortes ou fracos, e reimosos. A importância das classificações está na determinação de formas de preparo e consumo de alimentos..." ABDALA, 2007, p. 116-117. Ver também: BRANDÃO, op. cit. 1981; ORTENCIO, op. cit, 1981. Outro estudo clássico sobre as classificações de alimentos foi realizado por Klaas Woortman: WOORTMAN, Klaas. Quente, frio e reimoso: alimentos, corpo humano e pessoas. Caderno Espaço Feminino, Uberlândia, v. 1, n. 19, jan.jul. 2009.

53 MESQUITA, José Gonçalves de. Depoimento. Catalão, Fazenda Pires, jan. 2009. 
como também no que se refere à cura pelas plantas. Ela atendia demandas de mulheres grávidas que encomendavam a farinha de milho e o lombo de porco seco confeccionados por ela para a ocasião. No entanto, de acordo com seu relato, arroz não deveria ser ingerido, pois se considerava que provocaria inchaço da barriga. Engordar galinhas para o momento do resguardo também foi citado como hábito da região. Desta forma, feijão com lombo seco e farinha de milho e ensopado de galinha com farinha de milho eram receitas costumeiras das parturientes ${ }^{54}$.

\section{Considerações finais}

Nas duas pesquisas realizadas, a proposta foi elaborar um diagnóstico das práticas e saberes populares das regiões estudadas. Em que pesem os diferentes procedimentos adotados e distintos universos de análise, a história oral, centrada na memória de indivíduos com vistas a recuperar processos coletivos, propiciou registros amplos de aspectos concernentes à produção, à distribuição e ao consumo dos alimentos, observando ocasiões e lugares; modos de preparo e conservação; fatores de ordem socioeconômica e histórico-cultural. Além disso, vasta documentação e publicações foram produzidas de modo a divulgar os resultados obtidos e a estimular ações educativas e de preservação, assim como novos estudos.

Este artigo possibilitou refletir em conjunto sobre as duas experiências, fazendo ao mesmo tempo um balanço e uma retomada das análises à luz da relação entre alimentação, história e memória.

As transformações observadas nas regiões estudadas são inerentes ao próprio movimento de mudanças que ocorre no país como um todo e que não está descolado do processo global. No caso do sudeste goiano, as modificações resultam da política energética de um governo que pretende agir em nome do desenvolvimento da nação, a partir de uma proposta que subsume trajetórias e histórias individuais. Nesse quadro, documentar memórias é condição sine qua non, pois trata-se de eminente perda de bases

54 Conforme pudemos perceber, a dieta da parturiente descrita é bem semelhante à de Minas. Ver: ABDALA, M. C. Op. cit., 2007a, p. 130-131. 
que sustentam a reprodução de saberes e práticas cotidianas ancestrais que têm sua efetividade em espaços e circunstâncias específicas. Compreende-se, desse modo, a necessidade de sua reapropriação e ressignificação como expressões dos sentidos de continuidade para os atores envolvidos no processo.

Hábitos alimentares cotidianos representam modos de se organizar e de se relacionar e apontam a forma como costumes ancestrais são recriados no presente: os aromas e sabores carregam uma parte da história dos grupos. Nas diversas festividades religiosas, assim como na rotina diária, foi possível notar um padrão alimentar conservador, embora inovações e recriações também estejam presentes à mesa. Confirmamos a constatação do senhor Sidon de Sá Guimarães, folião do Divino Espírito Santo em Campo Alegre de Goiás e um de nossos entrevistados, que a culinária evolui, mas as pessoas continuam solicitando a comida "tradicional", de modo especial nas festas. Como referências identitárias, as tradições ancestrais, dentre elas a comida, nos propiciam senso de pertencimento e de continuidade entre passado e presente.

Festas e comidas são, portanto, pilares fundamentais da tradição e da identidade, constituindo um patrimônio cultural que sobrevive aos deslocamentos e ao tempo e que parte das novas gerações aprenderam a respeitar e a preservar como bem imaterial. Muitos jovens se engajam nesse ato de preservação da memória histórica com sua presença nos cultos, nas festas, nas reuniões para se rezar um terço. Mas se não participam dos eventos, preservam essa história ao rememorá-la, pois revivem, renovam e revigoram esses saberes.

É fato que não se pode subestimar o papel de agências governamentais na preservação do patrimônio histórico e cultural, incentivando a recriação de práticas e saberes, como é o caso da EMATER, do SENAC e das próprias Secretarias de Educação e Cultura de várias das cidades, que apoiam manifestações como artesanato e grupos de cultura popular locais. Um exemplo que citamos foi o de Campo Alegre de Goiás e a promoção das chamadas festas da terceira idade, realizando encontros de tecedeiras, de grupos de viola, terços cantados e promovendo a cultura tradicional. $\mathrm{O}$ Centro de Fiação e Tecelagem de Uberlândia-MG e o apoio da Prefeitura a alguns dos grupos da Congada são outras formas de expressão desse desempenho. De outro lado, aumenta o número de associações de artesãos, pequenos produtores, foliões e congadeiros que se organizam na perspectiva de defenderem a permanência de suas práticas tradicionais. Por sua vez, a 
academia tem contribuído para a perspectiva de reavivamento e preservação das manifestações da cultura imaterial por meio de pesquisas, a exemplo das nossas, que, de modo crescente, têm se dedicado ao estudo do tema e se comprometido com ações em prol dos grupos estudados.

Finalizando, é importante destacar que, quando foi possível observar o âmbito doméstico, notou-se que este permanece espaço privilegiado da mulher. Os homens estão presentes nas cozinhas das festas, dos restaurantes e na preparação dos churrascos, momentos em que se ocupam do trabalho tido como feminino. As mulheres, por sua vez, se ocupam da casa, dos filhos, do quintal e, na zona rural, também de alimentar as criações e de todas as tarefas, mesmo as mais pesadas que se fizerem necessárias, parceiras incondicionais da luta diária. Nas pequenas propriedades, a ausência de mão de obra só agrava esse tipo de sobrecarga do trabalho feminino. Em outros casos, a mulher vai para as cidades acompanhando os filhos(as) e, quando retorna ao campo, o faz apenas quando já estão crescidos(as) e encaminhados. É nesse quadro que muitas inovações ganham força. A comodidade do fogão a gás e do forno elétrico se sobrepõe ao inesquecível sabor da comida preparada no fogão e no forno a lenha, que inúmeras vezes a própria mulher tem de carregar e cortar. As compras no açougue se tornam mais constantes, o açúcar praticamente não é mais feito nas fazendas e pouco se planta o arroz e o café do dia a dia.

Nas localidades estudadas, as mudanças são visíveis e inevitáveis. Mas ainda permanecem alguns costumes herdados de geração para geração. Vez ou outra a saudade aperta e as brasas do fogão a lenha são acesas, as folhas de bananeira substituem os tabuleiros de alumínio na receita do biscoito, amarelada e engordurada de banha no caderno; a torradeira manual exala um aroma inesquecível de café, que penetra os sentidos e faz brotar memórias, reelaborando tradições alimentares e o próprio passado.

\section{Referências}

ABDALA, M. C. Mesas de Minas: as famílias vão ao self-service. Tese (Doutorado em Sociologia) - Faculdade de Filosofia, Letras e Ciências Humanas, Universidade de São Paulo. São Paulo, 2003. 
. Receita de mineiridade. 2. ed. Uberlândia: EDUFU, 2007a.

. Sabores da cultura popular: tradições e mudanças. In: MACHADO, M. C. T.; ABDALA, M. C. (Org.). Caleidoscópio de saberes e práticas populares. Catálogo de produção cultural do Triângulo Mineiro e Alto Paranaíba. Uberlândia: EDUFU, 2007b.

ARAÚJO, Daniel S. Sociabilidade e vizinhança nas comunidades rurais às margens do Rio São Marcos: permanências e mudanças. Trabalho de Conclusão de Curso (Graduação em Ciências Sociais) - Universidade Federal de Uberlândia. Uberlândia, 2010.

BOSI, E. Memória e sociedade: lembranças de velhos. São Paulo: Companhia das Letras, 1994.

BRANDÃO, Carlos Rodrigues. Plantar, colher, comer: um estudo sobre o campesinato goiano. Rio de Janeiro: Graal, 1981.

BRASILEIRO, Jeremias. Cultura afro-brasileira na escola. O congado em sala de aula. Uberlândia: Ed. Aline, 2009.

CANCLINI apud CARVALHO, José Jorge. O lugar da cultura tradicional na sociedade moderna. Brasília, DF: UnB, 1989. p. 7. (Série Antropologia, n. 77).

CANDIDO, Antonio. Os parceiros do Rio Bonito. São Paulo: Livraria Duas Cidades, 1982.

CASCUDO, Câmara. História da alimentação no Brasil. Belo Horizonte: Itatiaia: Edusp, 1983.

CAVALCANTI, M. L. V. de C. Culturas populares: múltiplas leituras. In: SEMINÁRIO NACIONAL DE POLÍTICAS PÚBLICAS PARA AS CULTURAS POPULARES, 2., 2005, Brasília. Anais... São Paulo: Instituto Pólis; Brasília, DF: Ministério da Cultura. 2005. p. 28-37.

DIESTE, C. P. Las cocinas regionales. Principio y fundamento etnográfico. In: CONGRESO INTERNACIONAL DE SOCIOLOGÍA RURAL, 7., Quito, Ecuador, nov. 2006. CD-Rom. Disponível em: <http://www.alasru.org/inscri/alasru2006.htm>. KATRIB, C. M.; MACHADO, M. C. T.; ABDALA, M. C. (Org.). São Marcos do sertão goiano. Uberlândia: EDUFU, 2010.

LONDRES, Cecília. Os inventários nas políticas de patrimônio imaterial. In: $\mathrm{Ce}$ lebrações e saberes da cultura popular: pesquisa, inventário, crítica, perspectivas. Rio de Janeiro: Funarte; IPHAN; CNFCP, 2004. p. 7-14.

MACHADO, M. C. T.; ABDALA, M. C. (Org.). Caleidoscópio de saberes e práticas populares. Catálogo de produção cultural do Triângulo Mineiro e Alto Paranaíba. Uberlândia: EDUFU, 2007. 
OLIVEIRA, C. A. A sobrevivência da ruralidade no entorno de Catalão-GO frente à modernização da agricultura do Centro-Oeste brasileiro. Revista do Centro de Ensino Superior de Catalão, CESUC, ano 4, n. 6, 1. sem. 2002.

OLIVEIRA, J. A.; BRANDÃO, C. R. Entre o murmúrio do rio e o despertar das lembranças. In: RAMIRES, J. C. L.; PESSÔA, V. L. S. (Org.). Geografia e pesquisa qualitativa: nas trilhas da investigação. Uberlândia: Assis Editora, 2009.

ORTENCIO, Bariani. Cozinha goiana: estudo e receituário. 2. ed. Goiânia: Oriente, 1981.

ORTIZ, Renato. Mundialização e cultura. São Paulo: Brasiliense, 1994.

ROBINS, K. Cultura global. In: HALL, Stuart. A questão da identidade cultural. 2. ed. Campinas, SP: UNICAMP, IFCH, fev. 1998. (Textos Didáticos, n. 18).

ROMERO, Sílvio. Cantos populares do Brasil. Introdução. [Dados de edição indisponíveis]. Disponível em: $<$ http://pt.wikisource.org/wiki/Cantos_populares_do_Brasil/Introdu\%C3\% A7\%C3\%A3o>. Acesso em: nov. 2009.

SANTOS, Márcia Pereira dos. O campo (re)inventado: transformações da cultura popular rural no sudeste goiano (1950-1990). 2001. Dissertação (Mestrado em História) - Universidade Federal de Uberlândia, Uberlândia, 2001.

UHE SERRA DO FACÃO. Projeto Básico Ambiental. Programa de Preservação do Patrimônio Histórico-Cultural, abril, 2002.

VIANNA, Letícia. Patrimônio imaterial: legislação e inventários culturais. In: $\mathrm{Ce}$ lebrações e saberes da cultura popular: pesquisa, inventário, crítica, perspectivas. Rio de Janeiro: Funarte, IPHAN, CNFCP, 2004.

WOORTMAN, Klaas. Quente, frio e reimoso: alimentos, corpo humano e pessoas. Caderno Espaço Feminino, Uberlândia, v. 1, n. 19, jan./jul. 2009.

Recebido em agosto de 2010. Aprovado em agosto de 2010. 